\title{
China's quest for natural resources in Latin America
}

\author{
Felipe Freitas da Rocha and Ricardo Bielschowsky ${ }^{1}$
}

\begin{abstract}
This article describes and analyses China's pursuit of natural resources in Latin America, particularly oil, iron, copper and soybeans, which account for over $70 \%$ of its imports from the region. This is motivated by the rapid growth and relative scarcity of natural resources in China itself, and the country's long-term planning that sees the region as a major supplier. In the case of oil, access occurs mainly through loans for oil and direct investments, while in iron and copper it is obtained through direct investments and imports. The method chosen by China to guarantee supply security seems to involve physical control of the resource in question. In the case of soybeans, the path chosen has involved imports increasingly intermediated by trading companies already present in the region, which have recently been taken over by China.
\end{abstract}

\section{Keywords}

China, imports, natural resources, petroleum, iron ore, copper ore, soy beans, economic relations, economic development, economic dependence, Latin America

\section{JEL classification}

$$
\text { O13, Q17, Q37 }
$$

\section{Authors}

Felipe Freitas da Rocha is a PhD candidate on the Postgraduate Program in Economics of the Institute of Economics at the Federal University of Rio de Janeiro (UFRJ), Brazil. Email: felipefreitasdarocha@hotmail.com.

Ricardo Bielschowsky is Associate Professor of the Institute of Economics at the Federal University of Rio de Janeiro (UFRJ), Brazil. Email: ricardo.bielschowsky@gmail.com. 


\section{Introduction}

China is building global commodity supply chains, for which purpose it seeks to trade with the largest possible number of producing countries; and, drawing on its more than US\$ 3.5 billion of reserves, it encourages its natural resource firms to invest abroad and directs its public banks to make loans repayable in oil and gas around the world.

The Latin American region plays an important role in China's strategy for gaining access to natural resources worldwide. Between 2000 and 2015, the value of Chinese imports originating in Latin America surged from US\$ 5 billion to US\$ 103 billion.

This article describes China's intense pursuit of natural resources in Latin America in recent years. In particular, it reviews the various strategies deployed to secure its supply of oil, iron ore, copper ore and refined copper and soybean and its derivatives, which in 2015 accounted for approximately $70 \%$ of China's imports from Latin America.

The article is divided into four parts, in addition to this introduction and the conclusion. In section II, the focus of the study is contextualized in theoretical and empirical terms. Section III then analyses Chinese access to Latin American oil and argues that, for economic rationality reasons, Chinese oil companies sell much of the Latin American oil under their control to the United States and within the region itself, while purchasing fuel from markets closer to China, which has characteristics better suited to its refining capacity. Section IV describes Chinese access to Latin American metallic minerals, focusing particularly on trade and foreign direct investment (FDI). The analysis concentrates specifically on copper (both ore and refined) and iron ore. Section $\vee$ then describes China's access to Latin American soybeans and analyses how its strategy of investing in trading firms avoids the legal uncertainty associated with land purchase in Latin America. The work concludes with some thoughts on the way Latin America responds to the Chinese quest for natural resources, which is considered inappropriate for the region's development. ${ }^{2}$

\section{Theoretical and empirical considerations}

\section{The Chinese pursuit of natural resources and the centre-periphery approach}

Although this article is essentially empirical, interest in the subject relates to the centre-periphery focus of the Economic Commission for Latin America and the Caribbean (ECLAC) and the "historical-structural" approach that characterizes the institution. The study was motivated by a perception that current Chinese involvement in Latin America represents a new historical trend that affects the region's production structures, by strengthening the commodity-export model. In particular, the perception that this engagement reflects a new type of centre-periphery relationship, to which the region seems to be increasingly subordinated, and which includes China as the new vehicle of dependency on the central economies. The analysis of the recent surge in Chinese interests in the region seeks to enhance understanding of the process of reconfiguring centre-periphery relations, which is currently unfolding in Latin America.

\footnotetext{
2 This article does not consider Chinese investments in natural resource access infrastructure because it this still an embryonic modality (although recurrently referenced by the press, such as the case of a potential interoceanic canal through Nicaragua and a possible railway connecting Brazil with the coast of Peru).
} 
As is well known, the centre-periphery model dates back to the origins of ECLAC, ${ }^{3}$ starting in the inaugural years of the organization under Raúl Prebisch (Prebisch, 1950; ECLAC, 1951). It was based on an analysis of the effects that trends in the central economies had on the countries of the region and the detection of an adverse long-term trend, based on slow technical progress and deteriorating terms of trade.

It was argued that, in the absence of well-managed industrialization - considered necessary but problematic, owing to poor production diversity, structural heterogeneity and an institutional framework that was unsuited to productive investment and technical progress (Rodríguez, 1981 and 2006; Bielschowsky, 1998 and 2009) - the region's international integration was destined to widen the gap in income and wealth relative to the central countries. The "dependency" theorizing of the 1960s and 1970s, generated a narrative in which the industrialization process unfolding in Latin America was seen as technologically and financially dependent on the centre. ${ }^{4}$

In the "lost decade" of the 1980s, caused by the debt with the banks that paralysed the region, and an initial perception of "financialization" (ECLAC, 1985) and passivity towards the unfolding technological revolution, the centre-periphery model continued to underlie the political-economy tradition of the regional reality -although the frequency with which the concepts "centre-periphery" and "dependency" are used may have diminished in those years as development theory faded. In the 1990s, the clear perception of "peripheral" behaviour was to be reinforced by the notion of subordination to financialization and the volatility of capital, generating major macroeconomic instability in Latin America (ECLAC, 1995), and the unfavourable conditions of Latin America's international engagement in the globalization of production (Di Filippo, 1998).

From the outset of the decade of 2000, China's performance in the region -and in its acknowledged new role as a central player - has constituted the new element that needs to be understood in depth, within the framework of the centre-periphery concept; for that reason, it deserves special empirical attention. This study contributes to that task.

Apart from being relatively sparse, research thus far into the quest for natural resources in Latin America has not invoked conventional theories relating to the internationalization of multinational enterprises. There are three reasons that explain the orientation of these studies and also the one followed in this article.

First, and as shown in this paper, conventional foreign direct investment (FDI) is only one of the avenues through which China gains access to Latin America's natural resources; in fact, FDI is relatively scarce in several natural-resource sectors (such as metals and food).

Second, Chinese FDI already existing in the region is almost entirely targeted on access to natural resources, so conventional theorizing on the subject has limited explanatory power. For example, Dunning's (1988) important theories on the search for an internal market, cheap labour, and technological assets are of little use in this case.

Third, and even more relevant, the behaviour of Chinese multinationals, especially in the natural resources sector, is essentially dictated by the planning interests of the Government of China. The latter is centralized and led by the Communist Party, which dictates the general orientation of the country's relations with Latin America, viewing the region as an important global source of raw materials.

The literature on the Chinese strategy for gaining access to natural resources shows that the interest of the Government of China is centred on national security and autonomy objectives, to enable it to grow in the long term (Corrêa, 2015; Jian, 2011; Peine, 2013; Sharma, 2014). These objectives are probably followed by three others, namely: to reduce the prices of the basic products they need; to find

3 For a good review of the centre-periphery approach, see Love (2007).

4 Expressed both in non-Marxist versions, such as Sunkel (1970), and Marxist versions, such as Dos Santos (1970). 
alternative ways to invest the country's foreign reserves (currently excessively biased towards United States Treasury securities); and to ease pressure for exchange-rate appreciation. It is thus reasonable to assume that Chinese multinational companies operating in the sphere of natural resources, whose key management posts respond to directives from the Central Committee of the Communist Party of China, are encouraged to seek investments, in the world at large and in Latin America in particular, as providers of strategic services to the Government of China. Although this does not mean they no longer pursue profit-seeking objectives, the behaviour of these firms in their internationalization in Latin America represents a research field that is yet to be explored, and analytical work still needs to be done.

The present article introduces some of the patterns of Chinese engagement in Latin America, which differ across sectors and convey a sense of pragmatic adaptation by China to the competitive contexts prevailing in each sector. Nonetheless, this study does not intend to launch a typology according to the specific behaviour of firms in each sector. In future work, the principle that Chinese firms' investment decisions in Latin America are influenced by the State will likely be combined with the conventional theoretical interpretation of the behaviour of transnational firms.

Rather than theorizing about multinationals, the empirical contribution made by this article is more closely related to research on the "curse of natural resources". As is well known, the work of Sachs and Warner (1995) revived an old debate about whether natural resources would be a blessing or a curse. The authors presented empirical evidence for, and verified the existence of, a negative relationship between natural resources and their predominance in the export model, on the one hand, and economic growth on the other. Various explanations have been put forward for this, ranging from "Dutch disease" and the theory of commodity-export-driven growth (staple theory), to institutionalist theories that argue that the abundance of natural resources is associated with barriers to democracy, capture of the State, corruption and the outbreak of civil wars. ${ }^{5}$

Clearly, if applied to the case of China's quest for natural resources in Latin America, the natural resource curse hypothesis would logically be that, by intensifying commodity-export activities, China's effect on Latin American development tends to be negative. In that sense, it would not differ from the conclusions drawn from Prebisch's theories in the late 1940s and 1950s on centre-periphery relations - which, not by coincidence are considered a precursor of the natural resource curse hypothesis. From the ECLAC standpoint, the problems of commodity-export specialization include its lack of innovative capacity, and the fact that productive chains tend to "leak" abroad, through imports, thereby slowing growth. No less relevant are claims that this form of specialization subjects economies to deteriorating terms of trade and tends to expose them to an income elasticity of import demand that is greater than the income elasticity of global demand for their exports, thereby generating balance of payments deficits and, consequently, hampering growth and development.

In recent years, ECLAC has contributed an approach that has some similarities with the natural resource curse model, through its work on "natural resource governance" (ECLAC, 2014; Bárcena and Prado, 2016; Altomonte and Sánchez, 2016). Although this study does not evaluate the development effects of investments in natural resources, arguments of this type are considered in the final section of the article.

\section{The importance of Latin American natural resources for China}

As a continental country with an area of 9.5 million $\mathrm{km}^{2}$, China has major fossil-fuel resources (coal, oil, natural gas), the world's greatest hydroelectric potential, large swathes of agricultural land and considerable metal reserves. Nonetheless, relative to the size of its population and economy, its resources are far

5 See, for example, Maciel (2015), which makes an extensive review of the literature on the natural resource curse and its different approaches. 
from abundant. Although it has for $19 \%$ of the world's population and generates $16.5 \%$ of global gross domestic product (GDP), China possesses 13\% of global reserves of coal, $8.5 \%$ of the world's iron ore, $4 \%$ of its copper ore, $2 \%$ of total oil reserves and $2 \%$ of all natural gas, plus $10 \%$ of all agricultural land and $6.5 \%$ of the world's fresh water.

This relative scarcity has been revealed in all its intensity by China's rapid growth. In the last 35 years, Chinese GDP has grown at an average rate of $10 \%$ per year and turned the country into the second largest economy on the planet, at the same time making its production and consumption increasingly dependent on commodity imports.

In addition to the relative shortage, the production of raw materials in China suffers from a number of specific problems, which make it even more difficult to significantly increase the domestic supply of natural resources: large mature oil fields with declining production (EIA, 2015); high production costs in iron ore and bauxite (Carvalho and others, 2014; Yu, 2011); a low ratio of reserves to production in the case of various minerals, such as copper (17 years), manganese (15 years), lead (7 years) and zinc (8 years), among others. In the case of soybeans, the country's food security policy has made cereal cropping more attractive than oilseed production (Gale, Hansen and Jewison, 2015; Wong and Huang, 2012; Sharma, 2014).

In 1996, China became a net importer of oil and soybeans; and, in 2007 and 2009, respectively, it became a net importer of natural gas and coal. Net oil imports increased from 1.2 million barrels per day in 2000 to 6.7 million in 2015; iron ore imports grew from 44 million fine tons in 2000 to about 580 million in 2015; those of copper expanded from 1.1 million fine tons in 2000 to 7.2 million in 2015; ${ }^{6}$ and soybean imports, which were at the level of 10 million tons in 2000, had surged to more than 82 million tons by 2015. The degree of China's reliance on imports of natural resources, measured as the ratio of net imports to consumption, is already $60 \%$ in the case of the main commodities, such as oil, copper and iron ore, and as high as $85 \%$ in the case of soybeans (see figure 1).

Figure 1

China: reliance on imports of selected raw materials, 1992-2014

(Percentages)

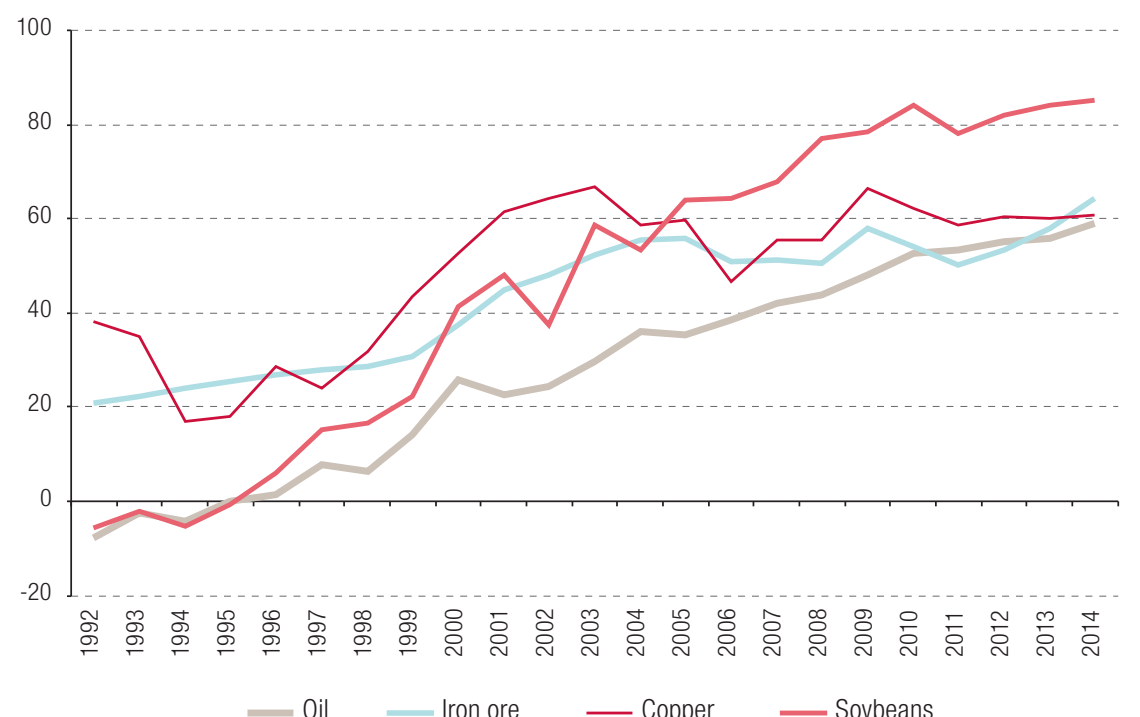

Source:Prepared by the authors, on the basis of F. F. Rocha, "Acesso chinês a recursos naturais na América Latina", Rio de Janeiro, Institute of Economics, Federal University of Rio de Janeiro (UFRJ), 2016.

6 In this study references to copper include both concentrates of this metal and refined copper. 
As Medeiros (2011, p. 211) notes, the twin processes of urbanization and heavy industrialization combine to make the Chinese pattern of accumulation intensive in natural-resources. Even with the expected shift towards a greater emphasis on domestic consumption as a source of growth, projections see the need for large-scale imports of natural resource-based commodities in the medium and long terms (Rocha, 2016).

China gains access to natural resources in ways that differ from sector to sector. The oil sector absorbs most of Chinese financing for production activity in Latin America, through loans repaid in oil (Gallagher, Irwin and Koleski, 2013). Oil, copper and iron absorb the majority of Chinese FDI in Latin America, which is undertaken by public companies (Chen and Pérez-Ludeña, 2014). In the case of soybeans, due to the legal difficulties associated with land purchase, the strategy has been to acquire two international trading companies that were already present in the region and seek to turn them into major operators in Latin America, in competition with the four main commodity traders, Archer Daniels Midland (ADM), Bunge, Cargill and Louis Dreyfus, collectively known as the "ABCD companies".

The relationship is profoundly unequal: China essentially views the Latin America as a source of raw materials; and, as argued in the conclusion to this article, Latin American governments and economic agents treat Chinese demand as just another market opportunity, rather than as an element to be harnessed for long-term sustainable development. ${ }^{7}$

\section{Chinese access to Latin American oil}

Chinese oil consumption more than doubled between 2000 and 2015, from 4.7 million to 10.8 million barrels per day. This has been driven mainly by burgeonng growth in gasoline and diesel consumption in the transport sector, resulting from expansion of the vehicle fleet (Rosen and Houser, 2007; IEA, 2012). Although industry is also a major consumer, its share of demand has shrunk from $50 \%$ in 2000 to $35 \%$ in 2013.

The International Energy Agency (IEA) predicts that Chinese demand for oil will increase by nearly 5 million barrels per day between 2014 and 2040, owing to the forecast vertiginous growth of the vehicle fleet, from 146 million units in 2014 to around 500 million by 2040 (IEA, 2015; EIA, 2014; Huo and Wang, 2012). It is estimated that, even with the use of improved oil extraction techniques and the development of oil production from compact formations (tight oil), Chinese oil production will dwindle over the next few decades, because its main oil fields products are mature and their output is declining (IEA, 2015; EIA, 2014). ${ }^{8}$ As a result, net imports of this fuel are expected to grow to between 12 million and 14.5 million barrels per day by 2040 , representing about $70 \%$ of Chinese consumption in that year (EIA, 2014; IEA, 2015; OPEC, 2015).

Among China's main supply sources (the Middle East, Africa, the Commonwealth of Independent States (CIS) and Latin America), its imports of Latin American oil grew by most between 2003 and 2015 (42\% per year). Having been virtually non-existent in 2003 , they had grown to around 854,000 barrels per day by 2015 , corresponding to $13 \%$ of China's oil imports and $8 \%$ of its consumption. Roughly 91\% of that amount was produced in three countries: the Bolivarian Republic of Venezuela (38\%), Brazil (33\%) and Colombia (21\%).

\footnotetext{
7 This does not mean China does not make investments in Latin American processing industries and services, just that those sectors are not considered a priority, and investments in them are still embryonic in the region.

8 If the price of oil remains low, the future investments of the large State oil companies could be affected and further reduce Chinese oil production in the medium and long terms (EIA, 2014 and 2015).
} 
China uses diplomacy to forge permanent trade links with other countries, both with respect to oil and for trade in general. In addition, as part of its autonomous development strategy, it also uses two instruments to secure its supply of oil, namely: direct investments by Chinese public companies, and financing by Chinese public banks which is repaid in barrels of oil. It is estimated that the first of these instruments has secured nearly 1.9 billion barrels of Latin American oil reserves, ${ }^{9}$ while the second -considering only the contracts signed in 2008-2011- covers about 2.3 billion barrels (the sum of these amounts is equivalent to approximately $17 \%$ of proven reserves in Chinese territory).

Chinese FDI first entered the Latin American oil sector through an investment made in Peru by the China National Petroleum Corporation (CNPC) in 1994. According to Ortiz Velásquez (2016), in addition to non-disclosure of the values involved, there are several problems in measuring Chinese investments. Bearing this proviso in mind, the available figures show that the process of gaining access to oil in this way has been rapid.

Between 2001 and 2013, at least 23 Chinese investment projects were undertaken with the aim of securing access to Latin American oil, with a known value of nearly US\$ 33 billion (Rocha, 2016). The four major Chinese State oil companies (CNPC, China National Offshore Oil Corporation (CNOOC), China Petroleum and Chemical Corporation (Sinopec) and the Sinochem Group) all entered Latin America in that period. As most of these investments in Latin America, both in value (US\$25.4 billion) and in number (15), were made between 2010 and 2013, China's investments in the region's oil sector are a recent phenomenon.

Chinese firms have preferred to access Latin American oil by acquiring rights over fields belonging to firms already established in the region, or else by taking over the firms that hold those rights. Recently, they have begun investing in more technologically challenging projects, such as deep-water drilling in the Libra oil field off the Brazilian coast.

The reserves of these firms in the region include 750 million barrels in the Bolivarian Republic of Venezuela, 700 million barrels in Brazil, 284 million barrels in Argentina and 140 million in Ecuador. China's oil production on Latin American soil amounts to almost 400,000 barrels per day (see table 1), producing mainly in the Bolivarian Republic of Venezuela (200,000 barrels per day), and also in Argentina (50,000), Brazil (46,000), Ecuador (43,000), Colombia $(28,000)$ and Peru $(20,000)$. In addition, CNPC has a project to produce 1 million barrels per day in the Bolivarian Republic of Venezuela in conjunction with Petróleos de Venezuela, S.A. (PDVSA). ${ }^{10}$ According to the National Agency of Petroleum, Natural Gas and Biofuels (ANP, 2014), production from the Libra field could attain 1.4 million barrels per day, generating a production equivalent of 140,000 barrels per day for both CNPC and CNOOC in Brazil. Accordingly, as China started to invest in Latin America only recently (2010-2013), its oil production on Latin American soil is likely to increase in the years to come.

Along with the expansion of imports and direct investments, since 2008 Chinese loans have been made with repayments in oil as a counterpart. The availability of reliable and disaggregated data on this modality is still sparse, and it is concentrated in 2008-2011.

\footnotetext{
9 This estimate could double if reserves in the Libra field are confirmed; and it does not include the MPE3 (Orimulsion) and Junín 10 fields, located in the Orinoco Belt (Bolivarian Republic of Venezuela), one of the largest oil reserves in the world.

10 See Bolivarian Republic of Venezuela (2014).
} 
Table 1

Estimation of Latin American oil under Chinese control (FDI and loans) whether or not exported to China, around 2014-2015

(Thousands of barrels per day)

\begin{tabular}{lccrrr}
\hline Country & $\begin{array}{c}\text { Production via } \\
\text { Chinese FDI }\end{array}$ & $\begin{array}{c}\text { Repayment of } \\
\text { Chinese loans }\end{array}$ & Total & $\begin{array}{c}\text { Sent to China } \\
\text { (Chinese imports) }\end{array}$ & Not sent to China \\
\hline Argentina & 50 & 0 & 50 & 6 & 43 \\
\hline Brazil & 46 & 200 & 246 & 141 & 105 \\
\hline Ecuador & 43 & 68 & 111 & 15 & 96 \\
\hline Peru & 19 & 0 & 19 & 0 & 19 \\
\hline Venezuela (Bolivarian Republic of) & 200 & 400 & 600 & 277 & 323 \\
\hline Subtotal & 358 & 668 & 1026 & 439 & 586 \\
\hline Colombia & 28 & 0 & 28 & 203 & 0 \\
\hline Others & 0 & 0 & 0 & 18 & 0 \\
\hline Subtotal & 28 & 0 & 28 & 221 & 586 \\
\hline Total & 386 & 668 & 1053 & 660 & 5 \\
\hline
\end{tabular}

Source:Prepared by the authors, on the basis of F. F. Rocha, "Acesso chinês a recursos naturais na América Latina", Rio de Janeiro, Institute of Economics, Federal University of Rio de Janeiro (UFRJ), 2016.

In that period, China signed nine such contracts in three of the region's countries: four in the Bolivarian Republic of Venezuela, with PDVSA, for a total of US\$ 32.6 billion, which will provide China with at least 1,300 million barrels of oil over 12 years; one in Brazil, with Petrobras, for US\$10 billion dollars, which will provide 700 million barrels of fuel to China over 10 years; and four in Ecuador, with EP Petroecuador (and the Ministry of Economy and Finance), for US\$ 5 billion, which will generate at least 300 million barrels of oil for China over a 10-year period. ${ }^{11}$ If these volumes are added to those underpinned by Chinese FDI, the country has already secured close to $10 \%$ of Brazil's oil reserves, $6 \%$ of Ecuador's, and $0.7 \%$ of those of the Bolivarian Republic of Venezuela.

This type of agreement involves more oil than is necessary to repay the loan. In all cases for which data are available, the time needed to pay back the loan principal (without accounting for interest) in barrels of oil is less than half the term of the agreement. In other words, oil is not being assigned to China simply to repay the debt, because there are contractual clauses that envisage sales to China after it has been paid.

In addition to directly securing rights to Latin American oil, loans for oil act as an additional way to facilitate access. Several cooperation agreements have been signed between China and Latin American countries as a result of Chinese loans (Downs, 2011; Sanderson and Forsythe, 2012; Alves, 2013). For example, in Brazil, after the Chinese loan for oil in 2009 to Petrobras, Sinopec and the Brazilian company also signed a strategic cooperation agreement, which gave the Chinese firm a share in two deepwater blocks along Brazil's north-eastern coast.

Another interesting feature is that the oil subject to these clauses can either be sent to China itself, or else it can be sold by the Chinese firms in other countries, at the exclusive discretion of the Chinese authorities (government, banks and State-owned companies). Furthermore, according to Jiang and Ding (2014), Chinese firms largely control how and to whom they sell their share of the output resulting from FDI. Between 2014 and 2015, loans for oil and investments enabled Chinese firms to control at least 1.05 million barrels per day of Latin American oil production (11\% of regional output). Owing to the type of oil obtained from Latin America (heavy and unsuited to Chinese refineries, which specialize

${ }^{11}$ Other agreements of this type have recently been signed or negotiated. For example, in 2013, China lent US\$ 5 billion to the Bolivarian Republic of Venezuela in exchange for sending 100,000 barrels of oil per day to China for three years (Gallagher and Myers, 2014); and, in 2015, new loans for oil were made in Brazil and the Bolivarian Republic of Venezuela (Myers, Gallagher and Yuan, 2016). In 2017 a contract for US\$ 5 billion was signed between Petrobras and China Development Bank (CDB), in return for 100 thousand barrels/day of oil for 10 years (Petrobras, 2016 and 2017). 
in light crude), ${ }^{12}$ together with the high cost of transportation to China, selling to the United States or Latin America itself has been preferred. ${ }^{13}$ As the former Minister of Trade and Industry of the Bolivarian Republic of Venezuela, Moisés Naim, remarked, "it's crazy to supply China from Venezuela" (Sanderson and Forsythe, 2012). The Chinese companies use the sale proceeds to buy oil in the Middle East and other regions closer to China, where the product has characteristics more compatible with its refining capacity. Thus, everything indicates that Chinese firms and banks are combining profit maximization strategies with the energy security policies dictated by their country's government.

China's priority is to secure ownership of the oil and the possibility of sending it directly to the country when deemed necessary. Table 1 shows that, in 2014-2015, it was only necessary to send to China less than half of the over 1,000 barrels per day that were under its control (either produced through Chinese FDI or appropriated as loan repayment). If all of this oil were shipped, it would represent about $20 \%$ of China's total imports in 2014. It should also be noted that investments are under way or planned that will reduce the cost constraint on importing from Latin America. Examples include Nicaragua's interoceanic canal and a refinery in Chinese territory to process the super heavy oil obtained from the Bolivarian Republic of Venezuela (EIA, 2015; Ray, Gallagher and Sarmiento, 2016).

Curiously, table 1 shows that China has very little claim on Colombia's oil and no oil business in Mexico, which are two of the four largest producing countries in the region, alongside the Bolivarian Republic of Venezuela and Brazil. This may indicate that the two countries are seen as areas subject to the geopolitical influence of the United States.

These procedures show that the Beijing authorities consider that the process of securing natural resources should not be entrusted to the free market, since it is of extreme national interest and fundamental for economic security. According to Downs (2011), although the China Development Bank (CDB), the leading Chinese financier in Latin America, has considerable autonomy, it is not a completely independent actor, since all its international projects require the approval of the Chinese Council of State. Furthermore, despite the reforms made to give more operational autonomy to the State oil companies, which can define tactics and objectives for global acquisitions, this did not mean strategic autonomy, since the main goals are established by the government (Corrêa, 2015). The Chinese Communist Party exercises control by directly or indirectly making appointments to the key positions in these firms (Jiang and Sinton, 2011; Corrêa, 2015).

\section{Chinese access to Latin American iron ore and copper}

In recent decades, the processes of industrialization, urbanization and infrastructure upgrading have fuelled rapid growth in China's demand for metals, including copper, aluminium and iron (Coates and Luu, 2012). Its apparent consumption of iron ore grew from 118 million fine tons in 2000 to 872 million in 2014, while its consumption of refined copper increased from 1.9 million to 10.9 million tons in the same period.

As the consumption of various metals is expected to remain high, and the production of several metallic minerals is unlikely to increase significantly, China will continue to rely heavily on mineral imports in the years to come. The World Bank (2014) sees the urbanization rate in China increasing from its current level of $54 \%$ to around $70 \%$ by 2030 . This means that China will have to accommodate roughly 300 million people in the cities over the next few years, in a process that will demand metal for

\footnotetext{
12 See Altomonte (2013), Winter and others (2013), Rosen and Houser (2007), Koch-Weser (2015) and Jiang and Sinton (2011).

13 See Winter and others (2013) and Koch-Weser (2015).
} 
infrastructure building. Moreover, Berkelmans and Wang (2012) note that Chinese buildings will require more metal per square metre because, with the high population density, they are being built ever higher. In addition, the expected large increase in the number of automobiles - which by itself will increase metal consumption - will stimulate demand for buildings with large underground garages.

Due to the scant domestic availability of scrap metal (Holloway, Roberts and Rush, 2010; Zhang and others, 2015), Chinese metal production will remain highly intensive in mineral consumption over the next few years. In turn, the domestic supply of various metallic minerals will remain low relative to demand, since the reserve-production ratio is low; so, unless large deposits are discovered, there is little room for a significant increase in production. Moreover, according to the World Bank (2016), the price of iron ore is likely to remain subdued until at least 2020, so the various Chinese producers will be unable to remain profitable (due to its high cost of production), and they will go out of business (Carvalho and others, 2014).

Latin America is important to China as a supplier of various metallic minerals. For example, in 2014, the region accounted for the following shares of Chinese imports: iron ore $21 \%$, copper 50\%, silver $41 \%$, zinc $32 \%$, lead $12 \%$, molybdenum $51 \%$ and tungsten $14 \%$. Nonetheless, while China's net imports of iron ore and copper amounted to US\$ 21 billion and US\$ 11 billion, respectively, in 2014, its deficit in all other metallic minerals in the region was just US\$ 2 billion in that year. Accordingly, this study focuses exclusively on iron ore, copper ore and refined copper.

Latin America is the second source region for Chinese imports of iron ore (23\% in 2015), after Oceania, rising from 17 million tons in 2000 to almost 220 million in 2015. Of this total, 192 million tons were produced in Brazil, 11 million tons in Peru, 10 million tons in Chile and 5 million tons in other Latin American countries. The three countries mentioned currently account for $98 \%$ of Chinese imports of iron ore from the region.

Following the 2008 crisis, Chinese imports of Latin American iron ore also grew partly as a result of a strategy implemented by the Vale mining company, which currently handles $80 \%$ of China's imports of this mineral from Latin America. In the wake of the crisis, Europe and Japan, which were its main buyers, cut their demand drastically, and this caused the firm to redirect its exports to the Chinese market (Vale, 2013). Moreover, the free trade agreements signed between China and Chile (2006) and between China and Peru (2010), the main objective of which was to guarantee Chinese access to metallic minerals (Roldán and others, 2016), boosted mineral trade between the region and China.

In the case of copper, Latin America is clearly the main source region for Chinese imports of this metal, with a share rising from $20 \%$ in the mid-1990s to almost $50 \%$ in 2015 . Volumes imported from Latin America grew from less than 100,000 fine tons of copper in the mid-1990s to over 3.5 million in 2015. In Latin America, China imports copper basically from Chile (66\% in 2015) and Peru (24.5\%), with smaller amounts sourced from Mexico (6\%) and Brazil (3\%).

In fact, the Latin American region is even more important for China than the trade data suggest, since the copper extracted in the region is also purchased by other countries that refine the metal and then export it to Chinese territory. For example, India, Japan and the Republic of Korea are all major suppliers of refined copper to China. ${ }^{14}$ Nonetheless, as the latter's production of refined copper is mainly based on primary refining, and the aforementioned countries do not produce the mineral in significant quantities, its production of refined copper means importing the mineral ore mostly from Latin America (over 60\% in 2014). In 2014, an estimated 400,000 tons of Latin American fine copper ore (just $6 \%$ of China's total copper imports in that year) were imported indirectly by China through those three countries.

\footnotetext{
${ }^{14}$ In 2014, these three countries supplied 10\% of Chinese copper imports (copper ore and refined copper).
} 
Chinese FDI in metals arrived in the region in the middle of the 2000 decade and thus far has had a relatively minor importance in China's access to Latin American metallic minerals. Nonetheless, there are strong reasons to suppose that these investments have already secured a significant amount of Latin American iron ore and copper ore for China, which will be accessed over the coming years (Rocha, 2016).

In keeping with the situation in China's mining sector, most of the firms that entered the region are State-owned, although private and hybrid companies have also ventured into the market. These firms prefer to access Latin American metallic minerals by acquiring majority rights over mines owned by firms already established in the region, or else by gaining control of the firms that hold those rights; and, also, over the mines that are already in an advanced stage of exploitation and technical quantification of reserves (Roldán and others, 2016).

In 2006-2014, 16 investments were made in the Latin American iron and copper mining sector, for a known value of nearly US\$11 billion (Rocha, 2016). Peru was the Latin American country that received the largest number of projects and the highest value in absolute terms. According to González-Vicente (2013), this is mainly explained by the trading relationship already existing between Peru and China (through the Shougang Group's investment in 1992), along with its ultraliberal mining investment regime, and its availability of primary resources.

The Shougang Group currently produces 7.3 million fine tons of iron ore per year and holds claims over 764 million fine tons of Peruvian reserves. This volume is equivalent to approximately $11 \%$ of the reserves existing in Chinese territory. Until 2015, the only other Chinese firm specializing in iron ore in the region was Wuhan Iron and Steel Corporation in Brazil, whose production -through a small 10.5\% stake in MMX Mineração e Metálicos - totalled just 180,000 fine tons. Guaranteed access is expected to increase in the future, however, as the mines of Pampa de Pongo (Nanjinzhao) in Peru, Vale do Rio Pardo (Honbridge Holdings) in Brazil and Oso Negro (Hebei Wenfeng) in Chile are developed and their resources are classified as reserves. Thus, while in 2014-2015 Chinese production of iron ore in Latin America amounted to some 7.5 million fine tons (equivalent to $5.4 \%$ of Chinese iron ore imports from Latin America in 2015), the coming on stream of the three projects (and the expansion of production from the Marcona mine by Shougang) mean that production should grow by nearly 30 million fine tons, to over 35 million (Rocha, 2016).

In the case of copper, China owns 20.7 million fine tons of Latin American reserves, equivalent to $70 \%$ of the reserves in Chinese territory. This does not include another potentially large volume to be determined in mining projects under the control of Chinese firms: El Galeno (Peru), Don Javier-Cercana (Peru), Panantza-San Carlos (Ecuador), Taltal (Chile) and La Plata (Chile). Of known reserves, 17 million fine tons are located in Peru (21\% of that country's reserves), 3.5 million in Ecuador and 270,000 in the Plurinational State of Bolivia.

The only Chinese firms that produce copper ore on Latin American soil are the Aluminium Corporation of China Limited (Chinalco) and the consortium composed of China Minmetals Corporation, Suzhou Guoxin and China International Trust and Investment Company (CITIC) (Minera Las Bambas), two very recent ventures in Peru. Considering that Chinalco's production began in mid-2014 and Minera Las Bambas came on stream as recently as December 2015, it can be assumed that the Chinese firm's production of 190,000 fine tons of copper ore in 2015 (11\% of Peruvian production) is bound to increase significantly as from 2016.

While China's production of copper ore in the region had secured only the equivalent of 5.3\% of its Latin American-sourced imports by 2015, it is estimated that in Peru alone it will grow by more than 1 million fine tons, to a level around 1.2 million fine tons by 2021 (Rocha, 2016). This is equivalent to about two thirds of current copper ore production in China itself ( 1.76 million fine tons in 2014). 


\section{Chinese access to Latin American soya}

China's rapid economic growth has been accompanied by major changes in diet, in terms of both the amount of food consumed and its composition. Because the income elasticity of demand for animal protein is high in China, income growth has fuelled a rapid increase in its consumption (mainly meat) (Ghose, 2014; Xing and Goldsmith, 2013). Moreover, as China is basically self-sufficient in the production of meat and soya meal, the increased demand for animal protein has boosted Chinese demand for soybeans. As a result, its consumption of the oilseed increased from about 10 million to 83 million tons between the early 1990s and 2014.

Westcott and Hansen (2016) estimate that Chinese soybean imports will top 100 million tons in early 2020. Although growth in the consumption of products of animal origin is likely to slacken (Xing and Goldsmith, 2013), the demand for soyameal will continue growing for a long time and, with it, the demand for soybeans. ${ }^{15}$

In terms of the domestic supply of soybeans, burgeoning Chinese urbanization and industrialization processes can be expected to reduce available arable land and cultivation areas (Ghose, 2014); and this process will be accentuated by water and soil pollution. Moreover, government policies foster cereal cropping and make this more profitable than soybean production, so that the area of the oilseed crop is unlikely to increase. The lack of access for Chinese soybean producers to the latest seed technology, compounded by the small scale of the farms and deficient agricultural practices, make it difficult to increase the productivity of the land, which has been flatlining since the mid-1990s (Clever and Xinping, 2016).

China's soybean imports from Latin America have been increasing since 1996 and, since 2000, have accounted for nearly $60 \%$ of its total soybean imports (the remaining $40 \%$ comes from North America). This means that Latin American countries supply nearly half of China's soybean consumption. In terms of concentration of production, China imports soybeans mainly from Brazil (77\% in 2015), Argentina (18\%) and, more recently, also from Uruguay (5\%).

Contrary to media reports, China is not gaining significant access to soybeans in the Latin American region through land grabbing FDI. Far from it, its strategy was inspired by the large transnational trading companies, which control the entire soybean production chain (except cultivation). The key to the strategy has been to acquire firms that already have a soybean marketing logistics infrastructure in the region.

According to recent literature (Hofman and Ho, 2012; Myers and Jie, 2015; Oliveira, 2015), although the media has reported several Chinese investments aimed acquiring land for planting, most of them never took place or were merely rumours. China did try to make this type of investment to gain access to soybeans, but the investors were blocked by restrictions imposed on foreigners purchasing land in Brazil (2010) and Argentina (2011).

Authors such as Myers and Jie (2015), Oliveira (2015) and Hofman and Ho (2012) agree that, in Latin America, concerns about land grabbing investments are misguided in the case of Chinese firms. The vast majority of such investments involve firms from the United States, Europe, Argentina and Japan. Oliveira (2015) offers an interesting explanation for this exaggerated concern in Brazil, by positing the existence of an alliance between Brazilian ranch owners (latifundistas), industry owners, free market economists and lawyers, who strategically exploit the media to stoke fear and have restrictions imposed that disproportionately affect Chinese investors (in land) in Brazil, so as to position themselves as the indispensable partners for Chinese investments (and also for firms of other nationalities). The author notes that the four major commodities trading companies mentioned above (Archer Daniels Midland

\footnotetext{
${ }^{15}$ According to Xing and Goldsmith (2013), Chinese soya meal consumption will be almost 70 million tons in 2020 and over 100 million tons in 2030. If it is assumed that $80 \%$ of the soybean consumed in China is processed (crushed) and that 1 ton of oilseed generates 0.78 tons of soya meal, the demand for soybeans will increase from 83 million tons in 2014 to approximately 112 million tons by 2020 and 165 million by 2030 .
} 
(ADM), Bunge, Cargill and Louis Dreyfus, known as the ABCDs) also strategically harness the media to divert attention from the very large influence they exert on investments in land around the world and, simultaneously, to oppose the growth of Chinese competition in international agribusiness.

Only two investments by Chinese-owned firms to acquire land to access Latin American soybeans actually have been confirmed. ${ }^{16}$ In 2007, the partnership between Zhejiang Fudi Agriculture Group and the Department of Agriculture of Heilongjiang Province purchased 16,800 hectares of Brazilian land (700 hectares in Rio Grande do Sul and 16,100 in Tocantins) for US\$ 48.6 million (Myers and Jie, 2015; Oliveira, 2015). The initial intention was to gain experience and then buy more land in Brazil, produce their own soya in the country and export it to China. Owing to administrative and operational problems, however, Zhejiang Fudi Agriculture Group sold its majority stake to Chongqing Grain Group (CGG) (another Chinese firm) in 2011. The second confirmed investment was undertaken by CGG towards the end of the 2000 decade, when it acquired a 52,000-hectare ranch in western Bahia, on lower-quality land that was not yet ready for soybean production (Oliveira, 2015). As of early 2014, this project was a long way from becoming operational (Reuters, 2014).

To understand China's strategy for securing access to Latin American soya in the context of restrictions on land purchases by foreigners in the region, it is necessary to consider the oilseed market between Latin America and China. According to Wesz Junior (2011 and 2014), following processes of production-chain verticalization and horizontalization in the last two decades, the soybean market in Latin America is controlled mainly by the ABCD companies. These four large trading companies control everything from financing and the provision of inputs and technical assistance, to the marketing of output (grain purchase, storage, industrialization, exports and sales in the domestic market).

In Brazil, these firms provide financing to soya producers through forward purchases of production. This is often done by delivering inputs through the production chain under their ownership. In other cases, when the financing is advanced in cash, the producers acquire the inputs (fertilizers, pesticides, seeds, among others) from the company that finances them. Thus, it is the trading company, which has its own logistic capacity (storage, marketing channels, ports for export) and processing capabilities, that will decide how the grains will be marketed (domestic market or export, grains or meal-oil). Arrangements of this type, which are used by the firms to obtain raw material, makes the producers heavily dependent on the trading companies, since a single actor becomes the financier, input supplier, technical assistance agent, buyer of the production and responsible for marketing (Wesz Junior, 2011).

In South America, even before the sowing season, poorly capitalized smallholders can commit up to two thirds of their harvest through this type of financing, while well capitalized farmers often assign a quarter of their output (Oliveira and Hecht, 2016, cited in Wesz Junior, 2016). In Argentina, the industrialized soybean export sector is also concentrated in very few companies, of which the ABCDs are the most important. According to Wesz Junior (2014), these firms control between $70 \%$ and $80 \%$ of all soya exports from Brazil and Argentina.

The ABCD companies have major oilseed processing capacity in China (Peine, 2013; Sharma, 2014). Thus, by controlling the marketing of soybeans in Latin America, they use their logistics capacity to market and export the oilseed to their own processing industries in China, transforming soybeans into meal or oil and selling to the Chinese market.

\footnotetext{
16 The purchase by Pengxin Group of 12,500 hectares of land in Santa Cruz (Plurinational State of Bolivia) for US\$27.2 million (Myers and Jie, 2015) can be considered a third investment, although, according to the company's website, the ranch is already in operation (soybean, corn and sorghum) but no Bolivian soya oil has been imported by China (or exported by the Plurinational State of Bolivia to China). Other examples of FDI include investments to open offices or enter the sector (or acquire fertilizers), and Pacific Century Group's purchase in Brazil of AIG assets in CalyxAgro in 2010. Pacific Century Group is a company based in Hong Kong and, according to Oliveira (2015), it is impossible to know how much Chinese capital it has relative to that of other nationalities.
} 
The Chinese strategy for gaining access to Latin American soya needs to be analysed in this context. Purchasing land without investments in logistics to market and export the production would make China dependent on large transnational corporations. For that reason, and as explained by Oliveira (2015), the Chinese firm Sanhe Hopeful would only be interested in financing soybean production after establishing itself as a grain terminal operator, either acquiring or building its own warehouses in the region, in order to export the soybeans purchased directly from Brazilian producers to supply their processing facilities in China.

To summarize, restrictions on land purchase by foreigners have only reinforced China's natural tendency to control soybean logistics and infrastructure. This explains why, in 2014, CBD and the Industrial and Commercial Bank of China (ICBC) lent US\$2.1 billion to Belgrano Cargas and Logística to restore and upgrade the rail network in Argentina (Wilkinson, Wesz Junior and Lopane, 2015; Gallagher and Myers, 2014). In 2010, Sanhe Hopeful acquired 20\% of a project to build a new grain terminal in the state of Santa Catarina (Oliveira, 2015). ${ }^{17}$ There is also a Chinese proposal to construct a transoceanic railway connecting the Atlantic Ocean in Brazil with the Pacific Ocean in Peru, possibly passing through the Plurinational State of Bolivia (Ray, Gallagher and Sarmiento, 2016). This project aims to link the Pacific ports of Peru to the new Brazilian soybean frontier.

The most significant entry of Chinese agribusiness capital into the Latin American soybean complex occurred through an acquisition negotiated outside Latin America, but which had the region as its main target (Oliveira, 2015). In 2014, the State-owned China National Cereals, Oils and Foodstuffs Corporation (COFCO) bought 51\% of Nidera (US\$1.2 billion) and Noble Agri (US\$1.5 billion) (Wilkinson, Wesz Junior and Lopane, 2015). In December 2015, COFCO acquired the remaining 49\% of Noble Agri (US\$ 750 million), thus securing sole ownership of the company. These investments avoid the challenges faced by Chinese greenfield investments in the soybean complex in Latin America, particularly those related to the bureaucracy involved in setting up businesses in the region, purchasing land and obtaining environmental permits.

The objective of COFCO when acquiring these firms is not to operate as a producer or a soybean processor itself, but as a trading company (Oliveira, 2015). In 2011, the president of the Chinese firm stated that the ABCD companies provided a good example for COFCO, given their successful participation throughout the entire industry supply chain (Myers and Jie, 2015). He explained that the firms in question are not involved in agricultural production, but they buy the harvests of local farmers and provide services and infrastructure.

Noble is present in Brazil, Argentina, Uruguay and Paraguay, in the soybean, coffee, sugar cane, biodiesel and cotton sectors. In the soya complex, the firm has a well developed logistics infrastructure, considerable storage capacity, soya processing units and a presence in activities in the upstream phases of the production chain, providing fertilizers, technical assistance and financing, like other global merchants. To gain an idea of the importance of this firm in the region, it is currently responsible for about $10 \%$ of all soybean exports from Argentina, as well as $5 \%$ of that country's exports of soya meal and 7\% in the case of soybean oil; and its 2014 exports in the region (Brazil, Argentina and Paraguay) amounted to US\$ 3 billion (FOB) (CIARA, undated; Wilkinson, Wesz Junior and Lopane, 2015).

The other firm acquired by COFCO, Nidera, also has a well-developed logistics infrastructure in the Latin American soya complex. It is present mainly in Brazil and Argentina and, to a lesser extent, in Uruguay (office and warehouse) and Paraguay (office). Its presence includes grain and fertilizer terminals and considerable storage capacity. It also acts in soybean processing, the production and marketing of seeds, the distribution of inputs (fertilizers, pesticides, and others) and the financing of producers, in addition to buying, storing and marketing cereals and oilseeds. Like Noble, Nidera is a major soya

\footnotetext{
${ }^{17}$ According to Oliveira (2015), the project has faced considerable opposition on social and environmental grounds; and, in early 2015 , construction had not started because the environmental permit and the decree of public utility had still not been issued.
} 
exporter in the region: the firm is currently responsible for $5 \%$ of Argentina's soybean exports, $7 \%$ of its soya meal exports and 9\% of its soya oil exports; and, in 2014, it accounted for over US\$ 3.5 billion (FOB) of the region's exports (Brazil, Argentina) (CIARA, undated; Wilkinson, Wesz Junior and Lopane, 2015).

In short, these two acquisitions enable COFCO to participate in financing activities, input provision, technical assistance and marketing of production in Latin America, and in processing soybeans in the form of meal or oil in China. This strategy has enabled it to avoid the problems faced by previous investments; and, at the same time, it has enabled China to become less dependent on transnational companies. The firm has established a solid presence in the Southern Cone soya complex, where its participation in the seed industry gives it advantages over the ABCD companies (Wilkinson, Wesz Junior and Lopane, 2015).

Lastly, it should be noted that there is another major path of access to Brazilian soybeans, which it was impossible to include in this study owing to lack of information. This involves foreign investment funds leasing soybean producing land, a modality that may already be in use in Latin America to circumvent the problem of land purchase restrictions. The fact that Chinese FDI is being targeted on soybean marketing and export logistics allows Chinese capital to spread through soya businesses by means of this "disguised" leasing. In the words of a specialist:

Thus, the strongest presence of foreign capital in soybean production within Brazil comes through specialized farm management companies and pools de siembra that channel multiple capital sources into the sector. More careful research of these capital sources has yet to be undertaken, and it is certainly the case that some Chinese capital was indeed being channeled into soybean production in Brazil through such means (cf. Nakatani et al 2014), particularly via the Pacific Century Group participation in CalyxAgro (Oliveira, 2015).

\section{Conclusion}

China's long-term growth dynamic depends, among other factors, on access to raw materials from around the world. Given their relative scarcity in China, securing external sources of long-term supply is one of the government's central objectives, which underlies a global diplomatic offensive aimed at diversifying import sources (Medeiros, 2008). The Going Global strategy, launched by the Government of China shortly after the turn of the century, is motivated mainly by reasons of national security and autonomy; but it also aims to change the terms of trade: China has sold its industrial products cheaply to conquer the international market; and it has paid high prices for the raw materials it needs in rapidly increasing amounts.

This article has made a much-needed evaluation of China's role in the ongoing reconfiguration of the "centre-periphery" relations to which Latin America has historically been subordinated. It has described and analysed China's quest for oil, metals (iron and copper) and soybeans in the region - products that currently account for over $70 \%$ of its imports from Latin America. The quest responds to the derived demand generated by China's rapid economic growth; and it is guided by long-term planning that sees Latin America as a major supplier of natural resources, given their abundance in the region.

The article has shown how access to oil is obtained mainly through loans for oil and through direct investments, while in the case of iron and copper it is obtained through direct investments and imports generally. In these cases, the path chosen by China to secure its supply seems to involve physical control of the resource. In the case of soybeans, the pragmatic path chosen has been imports increasingly intermediated by trading companies already present in the region and recently acquired by China. Another possible path, on which there is little information, could involve the leasing of land by investment funds with Chinese participation, which would be a way to avoid restrictions on land 
purchase by foreigners. Investments in infrastructure in exchange for access to natural resources in general - still embryonic and therefore not considered in this article- could also mobilize large-scale Chinese resources.

As happened over several centuries of its history, Latin America benefits from trade in raw materials in different ways: in addition to generating income and employment, it earns large amounts of foreign exchange, which is necessary for the expansion of its economies. As has been noted several times in the past, natural resources are not, in principle, a "punishment from God." Nonetheless, and as noted in the recent literature on the "curse of natural resources", current trends in relations with China (and Asia generally) seem far less promising for Latin America than they could be if the region's countries, either individually or collectively, had a strategy in place to maximize the potential benefits offered by their natural resource abundance. Latin America lacks a long-term development strategy to harmonize Chinese interests with more ambitious targets for economic and social progress than are currently guiding governments in the region.

There are at least five issues associated with foreign capital inflows into Latin America, and in particular with Chinese interests in natural resources, which require attention, in terms of what ECLAC calls the "new governance" of natural resources (ECLAC, 2014; Bárcena and Prado, 2016; Altomonte and Sánchez, 2016).

Firstly, whereas in China itself foreign capital is encouraged to enter into partnership with local capital, but subject to a series of counterpart requirements that benefit the growth of added value and local technical progress, Latin America is a free space for Chinese acquisitions without major demands being made.

Secondly, the high returns obtained from commodity exports are not always adequately taxed, or else are taxed in a precarious manner, in the cases of both domestic and foreign capital; consequently, they do not always generate benefits for the local population.

The third issue is that commodity production tends not to be labour-intensive and, even in the case of soybeans and other foods, the image projected is that of the old "mining enclave" activity, with no development of productive linkages or technical progress at the local level. There is a genuine concern that Latin America's economies are undergoing a process of "reprimarization", which is being accentuated by the fact that technical progress led by manufacturing industry in the developed countries excludes the region from the global generation and diffusion of technological capacity.

The fourth problem is that the foregoing is compounded by excessive exchange-rate appreciations. In periods of rising commodity prices, macroeconomic policy should avoid exchange-rate appreciations that conspire against investments in industrial production, paying special attention to the exchange-rate effects of short-term capital inflows, which usually accompany commodity boom periods but generate or aggravate external crises when the bonanza ends.

Last but not least, the robust expansion of natural resource exploitation driven by Chinese demand has not been accompanied by environmental care; and this has negative consequences both for local populations and for the planet as a whole.

If Latin American countries were to adopt national strategies - such as those of China itself and the United States - or both national and regional ones - such as those of European countries - they would be able to benefit much more from China's natural resource needs than they have thus far. It would be even better if the strategy were adopted by mutual agreement between the countries of the region, as an integrated regional strategy.

As part of this, the Latin American countries would need to strike a balance between nationalregional and global interests, to avoid becoming a stage for international disputes that do not benefit them. Until now, in global geopolitical terms, the region has been an area of initially European and, 
subsequently, American influence. The unprecedented speed of the Chinese surge in the region can be questioned by Westerners and, in particular, by the Americans; and there are signs of this happening, as noted above. Not without reason, that question, which is not considered in this article, is preoccupying an increasing number of analysts of United States-China relations in regard to Latin America, especially in view of the agreement between Brazil, the Russian Federation, India, China and South Africa, the so-called BRICS group (Paz, 2012; Nolte, 2013).

\section{Bibliography}

Altomonte, H. (2013), Natural resources: status and trends towards a regional development agenda in Latin America and the Caribbean. Contribution of the Economic Commission for Latin America and the Caribbean to the Community of Latin American and Caribbean States (LC/L.3748), Santiago, Economic Commission for Latin America and the Caribbean (ECLAC).

Altomonte, H. and R. J. Sánchez (2016), Hacia una nueva gobernanza de los recursos naturales en América Latina y el Caribe, ECLAC Books, No. 139 (LC/G.2679-P), Santiago, Economic Commission for Latin America and the Caribbean (ECLAC).

Alves, A. C. (2013), "Chinese economic statecraft: a comparative study of China's oil backed loans in Angola and Brazil", Journal of Current Chinese Affairs, vol. 42, No. 1.

ANP (National Agency of Petroleum, Natural Gas and Biofuels) (2014), "Consórcio vence $1^{a}$ rodada de licitações do pré-sal", 4 November [online] http://www.bdep.gov.br/?pg=6550\&m=libra\&t1=\&t2=libra\&t $3=\& t 4=\& a r=0 \& p s=1 \& 1464889931984$.

Bárcena, A. and A. Prado (2016), El imperativo de la igualdad: por un desarrollo sostenible en América Latina y el Caribe, Buenos Aires, Siglo XXI.

Berkelmans, L. and H. Wang (2012), "Chinese urban residential construction to 2040", RBA Research Discussion Papers, No. 2012-04, Sydney, Reserve Bank of Australia.

Bielschowsky, R. (2016), "Fifty years of ECLAC thought: a review", ECLAC Thinking: Selected Texts (1948-1998) (LC/G.26699), Santiago, Economic Commission for Latin America and the Caribbean (ECLAC)/Fondo de Cultura Económica.

(2009), "Sixty years of ECLAC: structuralism and neo-structuralism", CEPAL Review, No. 97 (LC/G.2400-P), Santiago, Economic Commission for Latin America and the Caribbean (ECLAC).

Bolivarian Republic of Venezuela (2014), "Venezuela y China producirán un millón de barriles diarios de petróleo", 14 May [online] http://china.embajada.gob.ve/index.php?option=com_content\&view=article\&id $=1087 \% 3$ Avenezuela-y-china-produciran-un-millon-de-barriles-diarios-de-petroleo\&catid=3\%3Anoticiasde-venezuela-en-el-mundo\&ltemid=17\&lang=es.

Carvalho, P. S. L. and others (2014), "Minério de ferro", BNDES Setorial, No. 39, Rio de Janeiro, National Bank for Economic and Social Development (BNDES).

Chen, T. and M. Pérez Ludeña (2014), "Chinese foreign direct investment in Latin America and the Caribbean", Production Development series, No. 195 (LC/L.3785), Santiago, Economic Commission for Latin America and the Caribbean (ECLAC).

CIARA (Argentine Oil Industry Chamber) (n/d), "Estadísticas" [online] http://www.ciaracec.com.ar/homeCiara.php.

Clever, J. and W. Xinping (2016), "Prospects for China's oilseed market remain strong", United States Department of Agriculture [online] https://gain.fas.usda.gov/Recent\%20GAIN\%20Publications/Oilseeds\%20and\%20 Products\%20Annual_Beijing_China\%20-\%20Peoples\%20Republic\%20of_3-29-2016.pdf.

Coates, B. and N. Luu (2012), "China's emergence in global commodity markets", Economic Roundup, No. 1.

Corrêa, A. P. (2015), "Industrialização, demanda energética e indústria de petróleo e gás na China", China em transformação: dimensões econômicas e geopolíticas do desenvolvimento, M. A. Macedo Cintra, E. B. da Silva Filho and E. Costa Pinto (orgs.), Rio de Janeiro, Institute of Applied Economic Research (IPEA).

Di Filippo, A. (1998), "La vision centro-periferia hoy", CEPAL Review, extraordinary issue (LC/G.2037-P), Santiago, Economic Commission for Latin America and the Caribbean (ECLAC).

Dos Santos, T. (1970), "The structure of dependence", The American Economic Review, vol. 60, No. 2, Nashville, Tennessee, American Economic Association.

Downs, E. (2011), Inside China, Inc: China Development Bank's Cross-Border Energy Deals, Washington, D.C., John L. Thornton China Center at Brookings. 
Dunning, J. H. (1988), "The eclectic paradigm of international production: a restatement and possible extensions", Journal of International Business Studies, vol. 19, No. 1, Palgrave Macmillan.

ECLAC (Economic Commission for Latin America and the Caribbean) (2014), Compacts for Equality: Towards a Sustainable Future (LC/G.2586(SES.35/3)), Santiago.

(1995), Latin America and the Caribbean: policies to improve linkages with the global economy, ECLAC Books, No. 40 (LC/G.1800/Rev.1-P), Santiago.

(1985), "Crisis and development: the present situation and future prospects of Latin America and the Caribbean" (LC/L.332(Sem.22/3)),vol. 1, Santiago.

(1951), Economic Survey of Latin America, 1949 (E/CN.12/164/Rev.1), New York, United Nations.

EIA (Energy Information Administration) (2015), "China”, 14 May [online] https://www.eia.gov/beta/international/ analysis. php?iso $=\mathrm{CHN}$. (2014), International Energy Outlook, 2014, September.

Gale, F., J. Hansen and M. Jewison (2015), "China's growing demand for agricultural imports", USDA-ERS Economic Information Bulletin, No. 136, Washington, D.C., Economic Research Service.

Gallagher, K. P., A. Irwin and K. Koleski (2013), "¿Un mejor trato?: análisis comparativo de los préstamos chinos en América Latina", Cuadernos de Trabajo del CECHIMEX, No. 19, Mexico City, National Autonomous University of Mexico (UNAM).

Gallagher, K. P. and M. Myers (2014), "China-Latin America Finance Database", The Dialogue [online] http:// www.thedialogue.org/map_list/.

Ghose, B. (2014), "Food security and food self-sufficiency in China: from past to 2050", Food and Energy Security, vol. 3, No. 2, Wiley.

González-Vicente, R. (2013), "Development dynamics of Chinese resource-based investment in Peru and Ecuador", Latin American Politics and Society, vol. 55, No. 1, Cambridge University Press.

Hofman, I. and P. Ho (2012), "China's 'developmental outsourcing': a critical examination of Chinese global 'land grabs' discourse", The Journal of Peasant Studies, vol. 39, No. 1, Routledge.

Holloway, J., I. Roberts y A. Rush (2010), "China's steel industry", RBA Bulletin, Sydney, Reserve Bank of Australia, December.

Huo, H. and M. Wang (2012), "Modeling future vehicle sales and stock in China", Energy Policy, vol. 43, Amsterdam, Elsevier.

IEA (International Energy Agency) (2015), World Energy Outlook, 2015, Paris. (2012), Oil and Gas Emergency Policy - China 2012 Update, Paris.

Jian, Z. (2011), China's Energy Security: Prospects, Challenges, and Opportunities, Washington, D.C., The Brookings Institution.

Jiang, J. and C. Ding (2014), Update on Overseas Investments by China's National Oil Companies: Achievements and Challenges since 2011, Paris, Organization for Economic Cooperation and Development (OECD)/ International Energy Agency (IEA).

Jiang, J. and J. Sinton (2011), Overseas Investments by Chinese National Oil Companies: Assessing the Drivers and Impacts, Paris, Organization for Economic Cooperation and Development (OECD)/International Energy Agency (IEA).

Koch-Weser, I. (2015), Chinese Energy Engagement with Latin America: A Review of Recent Findings, Washington, D.C., Inter-American Dialogue.

Love, J. L. (2007), "The Latin American contribution to centre-periphery perspectives: history and prospect", The Other Canon Foundation and Tallinn University of Technology Working Papers in Technology Governance and Economic Dynamics, No. 10, TUT Ragnar Nurkse Department of Innovation and Governance.

Maciel, G. da C. A. (2015), "Recursos naturais e desenvolvimento econômico: bênção, maldição ou oportunidade?", doctorate thesis, Rio de Janeiro, Institute of Economics, Federal University of Rio de Janeiro (UFRJ).

Medeiros, C. A. (2011), "Ascenção chinesa e as matérias-primas", Brasil e China no Reordenamento das relações Internacionais: Desafios e Oportunidades, Brasilia, Alexandre de Gusmão Foundation. (2008), "China: desenvolvimento econômico e ascensão internacional" [online] http://www.excedente. org/artigos/china-desenvolvimento-economico-e-ascensao-internacional/.

Myers, M., K. P. Gallager and F. Yuan (2016), Chinese Finance to LAC In 2015: Doubling Down, The Dialogue [online] https://www.thedialogue.org/wp-content/uploads/2016/02/Dialogue-LoansReport-v4-lowres.pdf.

Myers, M. and G. Jie (2015), China's Agricultural Investment in Latin America: A Critical Assessment, The Dialogue [online] http://www.thedialogue.org/wp-content/uploads/2015/06/Chinas-Agricultural-Investmentin-Latin-America.pdf. 
Nolte, D. (2013), "The dragon in the backyard: US visions of China's relations toward Latin America", Papel Político, vol. 18, No. 2, Bogota.

Oliveira, G. de L. T. (2015), "Chinese and other foreign investments in the Brazilian soybean complex", Working Paper, No. 9 [online] https://www.tni.org/files/download/bicas_working_paper_9_oliveira.pdf.

Oliveira, G. de L. T. and S. Hecht (2016), "Sacred groves, sacrifice zones and soy production: globalization, intensification and neo-nature in South America", The Journal of Peasant Studies, vol. 43, No. 2, Routledge.

OPEC (Organization of the Petroleum Exporting Countries) (2015), World Oil Outlook, 2015, Vienna.

Ortiz Velásquez, S. (2016), "Monitor de la OFDI de China en América Latina y el Caribe: aspectos metodológicos" [online] http://www.redalc-china.org/monitor/images/pdfs/Publicaciones/Ortiz_2016_Monitor_OFDI_ china_metodologicos.pdf.

Paz, G. S. (2012), "China, United States and hegemonic challenge in Latin America: an overview and some lessons from previous instances of hegemonic challenge in the region", The China Quarterly, vol. 209, Cambridge University Press.

Peine, E. K. (2013), "Trading on pork and beans: agribusiness and the construction of the Brazil-Chinasoy-pork commodity complex", The Ethics and Economics of Agrifood Competition, H. S. James (ed.), Dordrecht, Springer.

PETROBRAS (Petróleo Brasileiro) (2016), "Assinatura de termo de compromisso com o CDB", 26 February [online] http://www.investidorpetrobras.com.br/pt/comunicados-e-fatos-relevantes/fato-relevanteassinatura-de-termo-de-compromisso-com-o-cdb.

Prebisch, R. (1950), “The economic development of Latin America and its principal problems” (E/CN.12/89/Rev.1), New York, United Nations.

Ray, R., K. Gallagher and R. Sarmiento (2016), "China-Latin America economic bulletin: 2016 edition", Discussion Paper, No. 2016-3, Boston, Boston University.

REUTERS (2014), "Grande projeto agrícola da China na Bahia é, até agora, um campo vazio", 4 April [online] http://br.reuters.com/article/businessNews/idBRSPEA3303V20140404?sp=true.

Rocha, F. F. (2016), "Acesso chinês a recursos naturais na América Latina", Rio de Janeiro, Institute of Economics, Federal University of Rio de Janeiro (UFRJ).

Rodríguez, O. (2006), El estructuralismo latinoamericano, Mexico City, Siglo XXI/Economic Commission for Latin America and the Caribben (ECLAC). (1981), La teoría del subdesarrollo de la CEPAL, Mexico City, Siglo XXI.

Roldán, A. and others (2016), La presencia de China en América Latina: comercio, inversión y cooperación económica, Bogota, EAFIT University.

Rosen, D. H. and T. Houser (2007), "China Energy: A Guide for the Perplexed" [online] https://piie.com/ publications/papers/rosen0507.pdf.

Sachs, J. D. and A. M. Warner (1995), "Natural resource abundance and economic growth", NBER Working Paper, No. 5398, Cambridge, Massachusetts, National Bureau of Economic Research (NBER).

Sanderson, H. and M. Forsythe (2012), China's Superbank: Debt, Oil and Influence - How China Development Bank is Rewriting the Rules of Finance, Singapore, John Wiley \& Sons.

Sharma, S. (2014), The Need for Feed: China's Demand for Industrialized Meat and its Impacts, Institute for Agriculture and Trade Policy [online] https://www.iatp.org/sites/default/files/2017-5/2017_05_03_ FeedReport_f_web_0.pdf.

Sunkel, O. (1970), "Desarrollo, subdesarrollo, dependencia, marginación y desigualdades espaciales: hacia un enfoque totalizante", EURE, vol. 1, No. 1, Santiago.

Vale (2013), "Vale e China: 40 anos de parceria 1973-2013" [online] http://www.vale.com/PT/aboutvale/ news/Documents/china-quiz-8/pdf/40anosValeChina.pdf.

Westcott, P. and J. Hansen (2016), "USDA agricultural projections to 2025", United States Department of Agriculture [online] https://www.ers.usda.gov/publications/pub-details/?pubid=37818.

Wesz Junior, V. J. (2014), "O mercado da soja no Brasil e na Argentina: semelhanças, diferenças e interconexões", Revista de Ciencias Sociales, vol. 4, No. 1. (2011), Dinâmicas e estratégias das agroindústrias de soja no Brasil, Rio de Janeiro, E-papers.

Wilkinson, J., V. J. Wesz Junior and A. R. M. Lopane (2015), "Brazil, the Southern Cone, and China: the agribusiness connection", BRICS Initiative for Critical Agrarian Studies (BICAS) Working Paper, No. 16.

Winter, J. and others (2013), "Pacific Basin heavy oil refining capacity", SPP Research Paper, vol. 6, No. 8, Calgary, The School of Public Policy.

Wong, J. and Y. Huang (2012), "China's food security and its global implications", China: An International Journal, vol. 10, No. 1. 
World Bank (2016), Commodity Markets Outlook, Washington, D.C., January. (2014), Urban China: Toward Efficient, Inclusive, and Sustainable Urbanization, Washington, D.C.

Xing. L. and P. Goldsmith (2013), "Improving Chinese soybean meal demand estimation by addressing the noncommercial: commercial feed gap", China Agricultural Economic Review, vol. 5, No. 4, Emerald Publishing. Yu, Y. (2011), "Identifying the linkages between major mining commodity prices and China's economic growth - Implications for Latin America", IMF Working Papers, No. WP/11/86, Washington, D.C., International Monetary Fund (IMF).

Zhang, L. and others (2015), "The future of copper in China: a perspective based on analysis of copper flows and stocks", Science of the Total Environment, vol. 536, Amsterdam, Elsevier. 